\title{
Bilateral optic neuritis secondary to presumed ocular tuberculosis in immunocompetent adults
}

Diymitra K. Ganasan, Nurul Ain Shahrudin, Aida Zairani Mohd Zahidin, Safinaz Mohd Khialdin, Norshamsiah Md Din

Department of Ophthalmology, University Kebangsaan Malaysia Medical Centre, Wilayah Persekutuan Kuala Lumpur, Malaysia

\section{Abstract}

This case series aims to discuss cases of bilateral optic neuritis secondary to presumed ocular tuberculosis (TB) in two immunocompetent adults. Ocular TB has been associated with optic neuritis, but bilateral cases in immunocompetent individuals are rarely seen. We report a case series of two young healthy adults with bilateral painless optic neuritis as the presenting feature of ocular TB. Clinical examination, TB tests, and angiographic studies supported the diagnosis. All patients were started on anti-TB medication followed by oral prednisolone and had visual improvement a few weeks after treatment. As a conclusion, these cases highlight an atypical case of ocular TB presentation in immunocompetent individuals and thorough investigation is pertinent to preserve the visual function.

Keywords: immunocompetence, ocular tuberculosis, optic neuritis

Correspondence: Norshamsiah Md Din, MD (UKM), MS Ophthal (UKM), PhD (UK), Department of Ophthalmology, University Kebangsaan Malaysia Medical Centre, Jalan Yaacob Latiff, Bandar Tun Razak, 56000 Batu 9 Cheras, Wilayah Persekutuan Kuala Lumpur. E-mail:diymitra@gmail.com; shamsiahdr@hotmail.com 


\section{Neuritis optik bilateral akibat tuberkulosis okular andaian dalam kalangan orang dewasa yang immunokompeten}

\section{Abstrak}

Siri kes ini bertujuan untuk membincangkan kes-kes neuritis optik bilateral akibat tuberkulosis okular (TB) andaian dalam dua orang dewasa yang immunokompeten. TB okular selalunya dikaitkan dengan neuritis optik tetapi kes bilateral dalam individu immunokompeten adalah jarang dilihat. Kami melaporkan kes dua orang dewasa yang sihat tetapi mengalami neuritis optik bilateral yang tidak menyakitkan sebagai manifestasi TB okular. Pemeriksaan klinikal, ujian TB, dan kajian angiografi menyokong diagnosis. Semua pesakit dirawat dengan ubat antituberkulosis diikuti dengan ubat prednisolon oral dan pesakit mengalami kesan pemulihan penglihatan dalam masa beberapa minggu selepas rawatan. Sebagai kesimpulan, kes-kes ini memaparkan manifestasi TB okular yang jarang berlaku dalam kalangan individu dewasa yang immunokompeten dan siasatan menyeluruh adalah penting untuk memelihara fungsi visual pesakit.

Kata kunci: immunokompeten, tuberkulosis okular, neuritis optik

\section{Introduction}

Ocular tuberculosis presenting as optic neuritis has been seen in immunocompromised patients but bilateral cases in immunocompetent individuals are rarely seen. There are several reports regarding bilateral optic neuritis secondary to ocular TB in immunocompromised patients, but we found no report of bilateral tuberculous optic neuritis in immunocompetent patients. ${ }^{1}$ In this case series, we report two cases of ocular TB presenting with bilateral optic neuritis in immunocompetent adults.

\section{Materials and methods}

Case series. 


\section{Results}

\section{Case 1}

A 24-year-old gentleman presented with rapid progressive bilateral painless blurring of vision for 11 days preceded by 9 days history of high-grade fever. He denied any chronic cough, loss of weight or appetite, night sweats, or contact with others with such symptoms. He had travelled to Indonesia one week prior to the onset of fever.

Visual acuity was counting finger OD and 1/60 OS. Relative afferent pupillary defect (RAPD) was positive OD. The anterior chamber (AC) was quiet. Fundus examination revealed bilateral hyperaemic swollen optic discs (Figs. 1a and 1b) with intraretinal haemorrhage at the macula and grade 1 vitritis. Systemic examinations were normal. Fundus fluorescein angiography (FFA) revealed fluorescein leakage in both optic discs (Figs. 1c and 1d). Colour vision test was normal.

Mantoux test read $15 \mathrm{~mm}$ induration. However, erythrocyte sedimentation rate (ESR) was $11 \mathrm{~mm} /$ hour and chest X-ray was normal. Blood investigations for hepatitis, HIV, syphilis, and other infectious diseases were normal. Brain and orbit imaging showed no space occupying lesion.

The patient was treated with 4 daily tablets of Akurit (combination of pyrazinamide, ethambutol, isoniazid, and rifampicin) and oral prednisolone $1 \mathrm{mg} / \mathrm{kg} /$ day 3 days later. His vision subsequently improved to $6 / 24$ OD and 6/12 OS after 6 weeks of treatment, and further improved to $6 / 9$ OU after 3 months with resolution of disc swelling.

\section{Case 2}

A 31-year-old lady presented with painless blurring of vision in OD for two weeks. Relevant past history included recent travel to an area highly endemic for TB. There were no other ocular or systemic symptoms. She also denied contact with others with chronic cough. She had been treated elsewhere with oral prednisolone for 11 days prior to presentation.

Visual acuity was 6/24, N5 OD, and 6/9, N5 OS. RAPD was positive OD. There were occasional AC cells in OD. Optic disc was swollen and hyperaemic with multiple subretinal nodules in OD (Fig. 2a). The superior and inferior disc margin was blurred in OS (Fig. 2b). Systemic examination was unremarkable. Colour vision test was normal.

Initial investigations revealed positive rapid plasma reagin (RPR) with a titre of 1:16, with positive syphilis IgG and $\operatorname{IgM}$ and a Mantoux reading of $20 \mathrm{~mm}$. ESR and other infectious screening parameters were not significant. Chest X-ray, brain, and orbital imaging were normal. She was initially treated as ocular syphilis with intravenous C-penicillin 4 mega units. However, a week later her vision worsened to 6/60 N36 OD and 6/36 N8 OS. FFA showed optic disc leakage and choroiditis, but no vasculitic changes OD and 

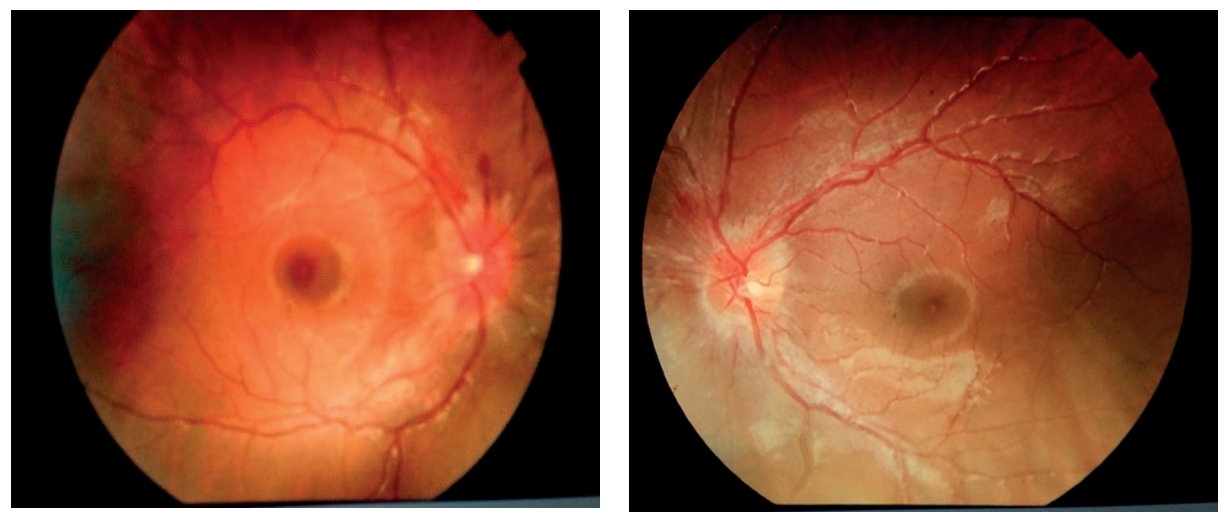

Fig. 1a-b. Colour fundus photograph showing bilateral hyperaemic swollen optic discs with intraretinal haemorrhage at the macula and grade 1 vitritis.
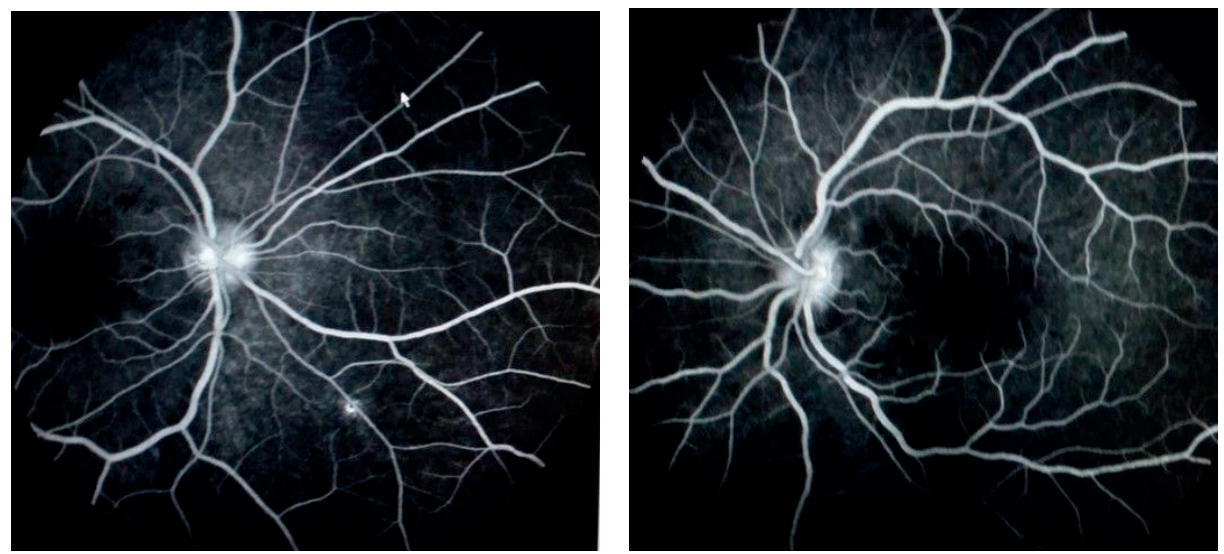

Fig. 1c-d. Fundus fluorescein angiography (FFA) showing fluorescein leakage in both optic discs. 

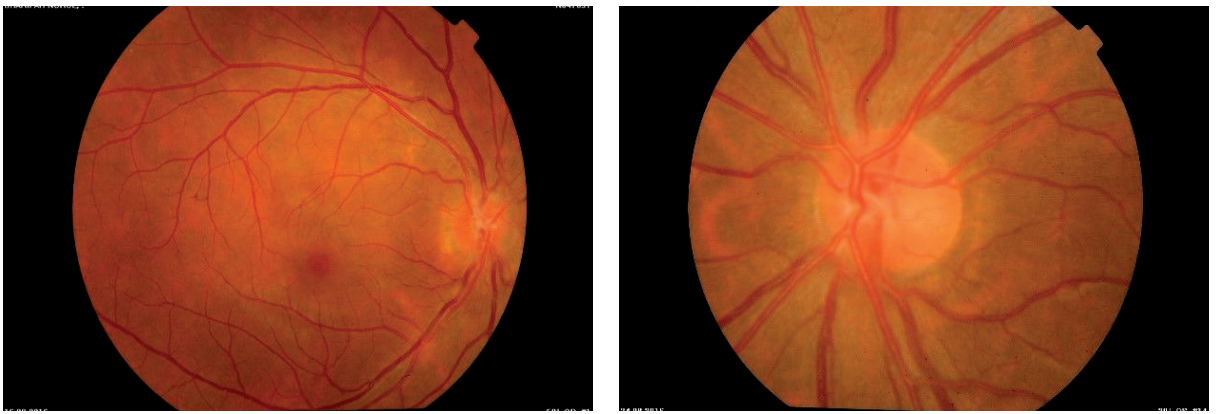

Fig. 2a-b. Colour fundus photograph showing swollen and hyperaemic optic disc with multiple subretinal nodules OD and blurred superior and inferior disc margin OS.
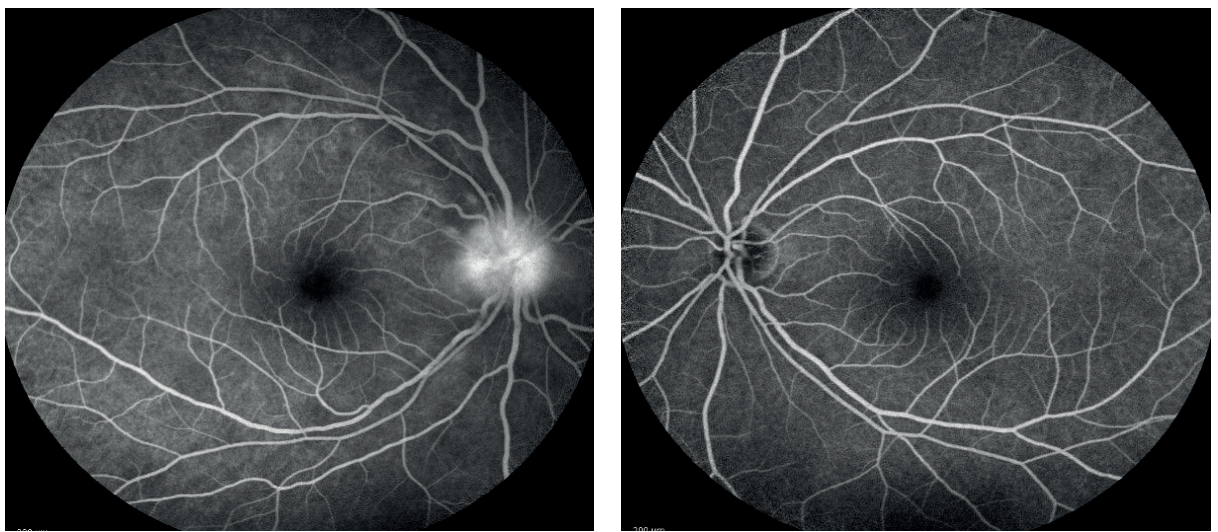

Fig. 2c-d. FFA showed optic disc leakage and choroiditis OD, but no vasculitic changes. No such changes were seen OS.
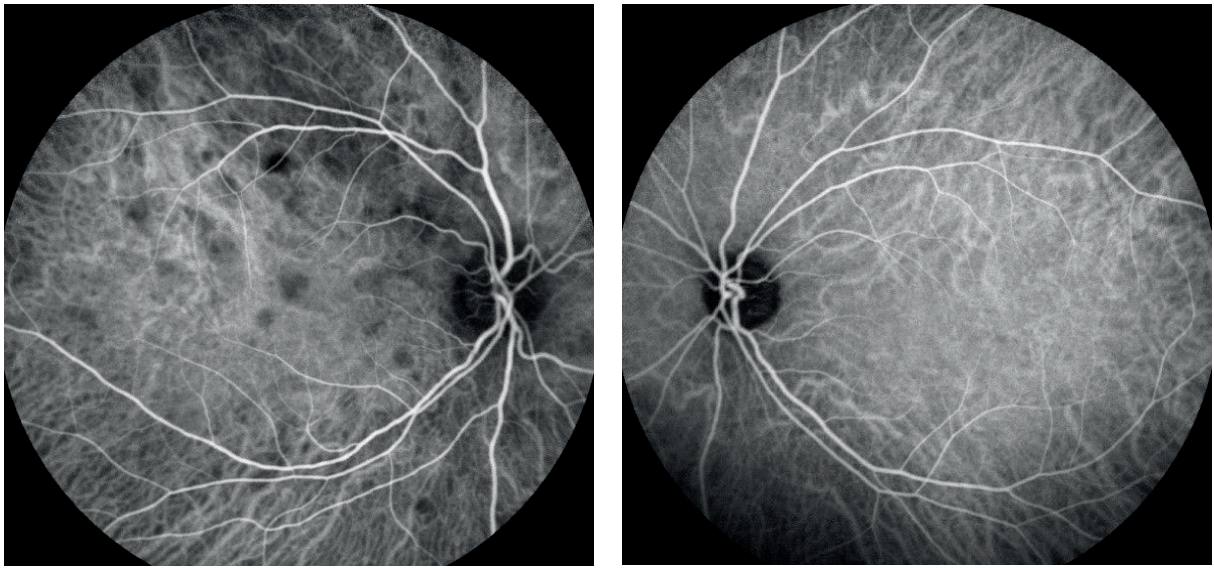

Fig. 2e-2. ICG angiography showed multiple hypofluorescence areas OD, indicating subretinal choroiditis. No such changes were seen OS. 
no optic disc leakage OS (Figs. 2c and 2d). Indocyanine Green angiography showed multiple hypofluorescence areas indicating subretinal nodules OD, but no such changes OS (Figs. 2e and 2f). Cerebrospinal fluid was negative for VDRL and TB PCR. The diagnosis was reviewed as ocular TB with systemic syphilis and anti-TB treatment was commenced, followed by oral prednisolone three days later same as the first patient. Her vision improved to $6 / 9 \mathrm{~N} 6 \mathrm{OU}$ after 3 weeks.

\section{Discussion}

Ocular TB is an important cause of infectious uveitis in Southeast Asia. The incidence of ocular TB is variable and is estimated to range from $1.4-5.7 \%$, with a higher percentage in immunocompromised patients. ${ }^{2}$

Ocular TB can result from haematogenous spread, from direct local extension from the skin, mucous membranes, or sinuses, and therefore results in posterior segment involvement such as papillitis, vitritis, retinitis, and choroiditis. ${ }^{3}$ In the anterior chamber, it is mostly seen as granulomatous uveitis. ${ }^{4}$ In both our cases, the chest X-rays were clear, indicating that these cases were not caused by dissemination from the lungs. In a few cases, ocular TB may occur due to direct entry of Mycobacterium tuberculosis into the ocular surface. The pathogenesis of the clinical manifestation is attributed to delayed hypersensitivity reaction. ${ }^{4}$

Definitive testing for TB is often limited and unreliable. Ocular fluid culture or PCR is inadequate due to the small volume and low bacillary concentration. Biopsy is also extremely difficult for lesions in the posterior retina, choroid, or optic nerve. Therefore, diagnosis generally depends on a combination of clinical findings and other supportive tests such as the Mantoux test, TB QuantiFERON, and typical angiographic findings. ${ }^{5}$ When used alone, TB QuantiFERON had limited value in differentiating between an acute and latent infection. However, negative TB QuantiFERON and Mantoux tests may allow for exclusion of active TB. ${ }^{6}$ In this case, it was also guided by TB medications and the response to it. In both our cases, patients were not keen for TB QuantiFERON testing.

In the second case, the patient had a positive RPR titre that led to an initial diagnosis of ocular syphilis. However, RPR may be falsely positive in tuberculosis, malaria, filariasis, aging, pregnancy, and immunization. ${ }^{7}$

FFA and ICG play an important role in diagnosis. On FFA, active tubercles appear hypofluorescent during the early phase and hyperfluorescent in the later phase. In our second case, initial angiographic studies did not show any changes in the left eye, possibly because the disease was still in its early phase. ICG tends to show lesions better than FFA, in which tuberculous chorioretinitis may remain hypofluorescent in all phases, either atrophic areas or active full-thickness granulomas. ${ }^{8}$

According to Malaysian Clinical Practice Guidelines (CPG), extrapulmonary TB and specifically ocular TB is treated with anti-TB drugs for at least six months. Our 
patients were treated with 4 daily tablets of Akurit followed by oral prednisolone 1 $\mathrm{mg} / \mathrm{kg} /$ day 3 days later. The CPG advocates for use of systemic corticosteroids in tuberculous meningitis and pericarditis. ${ }^{9}$ However, steroid therapy in ocular TB is not well documented. ${ }^{10}$ Systemic steroids in combination with ATT are occasionally used in patients with persistent ocular inflammation or retinal vasculitis, but there are no clinical trials to prove their efficacy. However, corticosteroids (topical and/or oral) may be used to control the inflammation following the Type IV hypersensitivity reaction. They are generally tapered over $6-12$ weeks. ${ }^{11}$

Bilateral tuberculous optic neuritis can occur in healthy young individuals and can be asymmetrical in presentation of blurring of vision. Treatment with the standard anti-TB agents combined with systemic steroids show promising visual outcome. These cases highlight a new trend of ocular TB presentation in immunocompetent individuals and thorough investigation is pertinent to preserve the visual function.

\section{References}

1. Chakraborty D. Atypical optic neuritis in a patient of HIV with lymph node tuberculosis. Delhi Journal of Ophthalmology. 2014;24(3):209-210

2. Non-indexed. Ching WL, Min SC, Mohtar I. Ocular tuberculosis-a blinding eye infection. International Eye Science. 2012;12(5):817-818

3. Sridharan S, Biswas J. Ocular tuberculosis: an update. Expert Rev Ophthalmol. 2007;2(5):845-860.

4. Shahidatul-Adha M, Zunaina E, Liza-Sharmini A, et al. Ocular tuberculosis in Hospital Universiti Sains Malaysia - A case series. Ann Med Surg. 2017;24:25-30.

5. Sheu S, Shyu J, Chen L, Chen Y, Chirn S, Wang J. Ocular manifestations of tuberculosis. Ophthalmology. 2001;108(9):1580-1585.

6. Xia H, Wang X, Li F, et al. Diagnostic values of the QuantiFERON-TB gold in-tube assay carried out in China for diagnosing pulmonary tuberculosis. PLoS One. 2015;10(4):e0121021.

7. Nayak S, Acharjya B. VDRL test and its interpretation. Indian J Dermatol Venereol Leprol. 2012;57(1):3.

8. Wolfensberger T, Piguet B, Herbort C. Indocyanine green angiographic features in tuberculous chorioretinitis. Am J Ophthalmol. 1999;127(3):350-353.

9. Ministry of Health. Management of Tuberculosis. 3rd edition. 2012.

10. Ocular Tuberculosis (TB) - Asia Pacific [Internet]. American Academy of Ophthalmology. 2018 [cited 4 October 2018]. Available from: https://www.aao.org/topic-detail/ocular-tuberculosis-tb--asia-pacific-2

11. Souissi S, David T, Beral L. Steroid treatment in ocular tuberculosis: A double-edged sword? J Fr Ophtalmol. 2017;40(2):126-132. 